\title{
Bacteroides coprophilus sp. nov., isolated from human faeces
}

\author{
Hidenori Hayashi, ${ }^{1} \dagger$ Kensaku Shibata, ${ }^{1,2}$ Mohammad Abdul Bakir, ${ }^{1}$ \\ Mitsuo Sakamoto, ${ }^{1}$ Shinichi Tomita ${ }^{2}$ and Yoshimi Benno ${ }^{1}$ \\ ${ }^{1}$ Microbe Division/Japan Collection of Microorganisms, RIKEN BioResource Center, \\ 2-1 Hirosawa, Wako, Saitama 351-0198, Japan \\ ${ }^{2}$ Department of Life Science, Faculty of Agriculture, Tamagawa University, \\ 6-1-1 Tamagawa-Gakuen, Machida, Tokyo 194-8610, Japan
}

\begin{abstract}
Three Gram-negative, anaerobic, rod-shaped bacteria (strains CB40, CB41 and CB42 ${ }^{\top}$ ) were isolated from human faeces. Based on phylogenetic analysis and specific phenotypic characteristics, these strains were included in the genus Bacteroides, and 16S rRNA gene sequence analysis indicated that these strains represented a novel species. The strains were most closely related to the type strains of Bacteroides barnesiae and Bacteroides salanitronis, with sequence similarities of 93.4 and $89.8 \%$, respectively. The $\mathrm{G}+\mathrm{C}$ content of strain $\mathrm{CB} 42^{\top}$ is $44.7 \mathrm{~mol} \%$. Major fatty acids were anteiso- $\mathrm{C}_{15: 0}, \mathrm{C}_{16: 0}$, iso- $\mathrm{C}_{17: 0} 3-\mathrm{OH}$ and $\mathrm{C}_{18: 1} \omega 9 \mathrm{c}$. On the basis of the data presented, a novel Bacteroides species, Bacteroides coprophilus sp. nov., is proposed, with $\mathrm{CB}^{2} 2^{\top}\left(=\mathrm{JCM} 13818^{\top}=\mathrm{DSM} 18228^{\mathrm{T}}\right)$ as the type strain.
\end{abstract}

The culture-independent approach based on 16S rRNA gene sequence analysis has made it possible to clarify the dominant microbiota of the human gut (Eckburg et al., 2005; Suau et al., 1999; Wilson \& Blitchington, 1996; Zoetendal et al., 1998). We have previously reported that the human faecal microbiota can be analysed based on $16 \mathrm{~S}$ rRNA gene libraries and strictly anaerobic culture-based methodologies (Hayashi et al., 2002a, b). We have detected many potentially novel species that have not yet been characterized and have demonstrated correlations between novel isolates and 16S rRNA gene sequences. Among the isolates that we have studied are some that have been shown to be representatives of novel species of the genus Bacteroides (Hayashi et al., 2002a, b). Some potential novel species belonging to the genus Bacteroides have also been observed from 16S rRNA gene sequence libraries (Eckburg et al., 2005; Hayashi et al., 2002a; Suau et al., 1999). Bacteroides is one of the predominant genera in the human gut microbiota (Benno et al., 1989; Finegold et al., 1983; Hayashi et al., 2002a, b). Recently, five novel species belonging to the genus Bacteroides (Bacteroides coprocola, B. dorei, B. finegoldii, $B$.

tPresent address: Faculty of Engineering, Maebashi Institute of Technology, 460-1 Kamisatori, Maebashi, Gunma 371-0816, Japan.

The GenBank/EMBL/DDBJ accession numbers for the 16S rRNA gene sequences of strains CB40, CB41 and CB42 ${ }^{\top}$ are AB064919, AB260025 and AB260026.

Tables detailing API 20A and Rapid ID 32A test results and the cellular fatty acid composition of strains of $B$. coprophilus sp. nov. and related species are available as supplementary material with the online version of this paper. intestinalis and B. plebius) that were isolated from human faeces have been described (Bakir et al., 2006a, b, c; Kitahara et al., 2005). The $16 \mathrm{~S}$ rRNA gene sequences of these species corresponded to undescribed sequences detected in $16 \mathrm{~S}$ rRNA gene sequence libraries derived from human faecal samples (Eckburg et al., 2005; Hayashi et al., 2002a). Here we describe a novel species belonging to the genus Bacteroides that was isolated from human faeces by using a strictly anaerobic culture-based method.

The strains used in the present study were maintained on Eggerth Gagnon (EG) agar (Merck) supplemented with $5 \%$ $(\mathrm{v} / \mathrm{v})$ horse blood for 2 days at $37^{\circ} \mathrm{C}$, in an atmosphere of $100 \% \mathrm{CO}_{2}$. Strains $\mathrm{CB} 40, \mathrm{CB} 41$ and $\mathrm{CB} 42^{\mathrm{T}}$ were isolated from the faeces of a healthy Japanese male ( 52 years old) by using medium 10 and the 'plate in bottle' method as described by Hayashi et al. (2002a) and Mitsuoka et al. (1969). Briefly, after collecting samples, each $0.5 \mathrm{~g}$ faecal sample was immediately suspended in dilution buffer, and $50 \mu \mathrm{l}$ of $10^{8}$-diluted faecal samples were plated anaerobically on medium 10 by using the 'plate in bottle' filled with $100 \%$ $\mathrm{CO}_{2}$. Bile resistance was tested by growing the bacteria on GAM (Nissui) agar plates supplemented with $2 \%$ Bacto oxgall (Difco). Physiological, biochemical and enzyme activity tests were performed by inoculation of API 20A and Rapid ID 32A (bioMérieux) test strips according to the manufacturer's instructions and incubation at $37^{\circ} \mathrm{C}$ in an anaerobic jar. The isolates were cultured in PYG broth for analysis of metabolic end products (Sakamoto et al., 2004, 2005). The metabolic end products were prepared as described by Holdeman et al. (1977) and analysed as described by Sakamoto et al. $(2004,2005)$. Cellular fatty acid 
profiles were determined by using the MIDI microbial identification system (Microbial ID). Saponification, methylation, extraction and determination of cellular fatty acid profiles were conducted as described by Sakamoto $\mathrm{et} \mathrm{al}$. (2002). Genomic DNA was extracted from cells harvested from GAM broth as described by Sakka et al. (1989). Briefly, cells were suspended in buffer A $(10 \mathrm{mM}$ Tris/ $\mathrm{HCl}$ and 10 mM EDTA, pH 8.0) containing lysozyme $\left(1 \mathrm{mg} \mathrm{ml}^{-1}\right)$. After incubation at $37^{\circ} \mathrm{C}$ for $5 \mathrm{~min}, 0.1$ vols $10 \%$ SDS was added, and the suspension was incubated at $60{ }^{\circ} \mathrm{C}$ for $30 \mathrm{~min}$. The $\mathrm{G}+\mathrm{C}$ content of the DNA was determined by using the HPLC method (Kitahara et al., 2001; Tamaoka \& Komagata, 1984). The $16 \mathrm{~S}$ rRNA gene was analysed as described by Hayashi et al. (2002a). Sequence data were aligned with the CLUSTAL W (Thompson et al., 1994) package and corrected by manual inspection. Nucleotide substitution rates ( $K_{\text {nuc }}$ values) were calculated and phylogenetic trees were constructed by using the neighbour-joining method (Kimura, 1980; Saitou \& Nei, 1987). Bootstrap resampling analysis (Felsenstein, 1985) of 100 replicates was performed to estimate the confidence of tree topologies.

Cells of strains CB40, CB41 and CB42 ${ }^{\mathrm{T}}$ were obligately anaerobic, non-spore-forming, non-motile, Gram-negative short rods or rods. Cells on EG agar were $0.7-0.8 \times$ $2.5-4.1 \mu \mathrm{m}$ in size and occurred singly. Colonies were 0.5-1.2 $\mathrm{mm}$ in diameter, dark grey, translucent, lustrous, circular and slightly convex on EG agar plates. The three new strains could be differentiated from Bacteroides barnesiae JCM $13652^{\mathrm{T}}$ and Bacteroides salanitronis JCM $13657^{\mathrm{T}}$ based on fermentation of L-arabinose, D-cellobiose, L-rhamnose, salicin and D-xylose (see Supplementary Table S1 in IJSEM Online). Based on Rapid ID 32A test results, the new strains could be differentiated from B. barnesiae JCM $13652^{\mathrm{T}}$ and $B$. salanitronis JCM $13657^{\mathrm{T}}$ based on activity data for $\alpha$ arabinosidase, $N$-acetyl- $\beta$-glucosaminidase, $\alpha$-fucosidase and arginine, glycine, glutamyl glutamic acid, histidine, leucine, phenylalanine, serine and tyrosine arylamidases (see Supplementary Table S2 in IJSEM Online).

The cellular fatty acid composition of Bacteroides species has been determined (Mayberry et al., 1982; Miyagawa et al., 1979; Shah \& Collins, 1980) and used to provide a classification for the genus (Shah \& Collins, 1983). The major cellular fatty acids of strains CB40, CB41 and CB42 ${ }^{\mathrm{T}}$ were anteiso- $\mathrm{C}_{15: 0}, \mathrm{C}_{16: 0}$, iso- $\mathrm{C}_{17: 0} 3-\mathrm{OH}$ and $\mathrm{C}_{18: 1} \omega 9 c$ (see Supplementary Table S3 in IJSEM Online).

The lengths of the 16S rRNA gene sequences of strains CB40, CB41 and CB42 ${ }^{\mathrm{T}}$ obtained in this study were about 1500 bases, and phylogenetic analysis was based on about 1472 aligned homologous nucleotides (Escherichia coli positions 8-1492). The phylogenetic tree clearly indicated that these strains were related to strains within the genus Bacteroides (Fig. 1). The three novel strains formed a single cluster and a distinct line of descent; their 16S rRNA gene sequences were identical. Highest sequence similarity to strain $\mathrm{CB} 42^{\mathrm{T}}$ was found with B. barnesiae JCM $13652^{\mathrm{T}}$ (93.4\%), indicating that strain $\mathrm{CB} 42^{\mathrm{T}}$ could represent a novel species (similarity $<97 \%$ to the closest related species; Stackebrandt \& Goebel, 1994). The DNA G + C contents of strains CB40, CB41 and $\mathrm{CB} 42^{\mathrm{T}}$ were $44.2-45.2 \mathrm{~mol} \%$.

Matsuki et al. (2004) analysed the human gut microbiota by real-time PCR using a Bacteroides fragilis group-specific primer set. The $B$. fragilis group was detected from all subjects at a level of antilog $9.9 \pm 0.3$ cells g $^{-1}$ (wet wt).

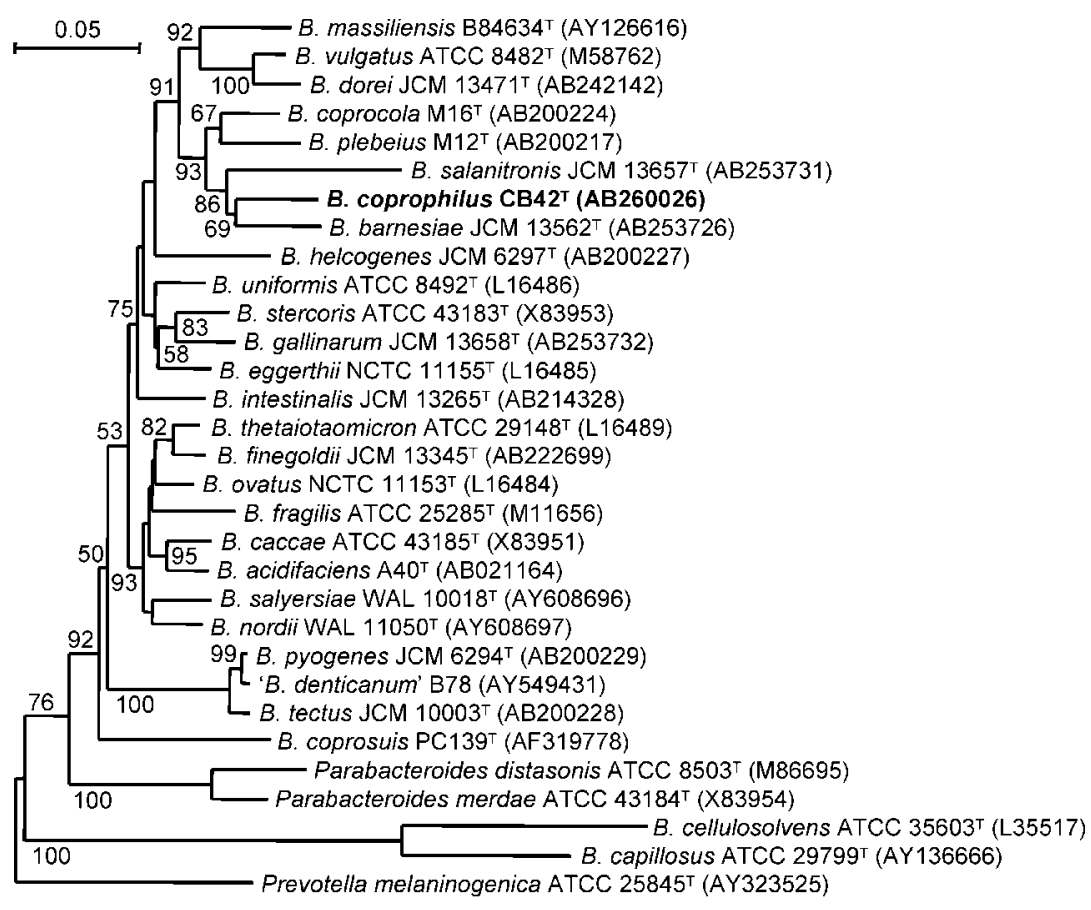

Fig. 1. Phylogenetic tree showing the relationship between strain $\mathrm{CB} 42^{\top}$ and related Bacteroides species. The tree was constructed by using the neighbour-joining method based on 16S rRNA gene sequences. The sequences of strains CB40 and CB41 were identical to that of strain $\mathrm{CB} 42^{\top}$. Bootstrap values (from 100 replicates) of $\geqslant 50$ are shown. The sequence of Prevotella melaninogenica ATCC $25845^{\top}$ was used as the outgroup for rooting the tree. Bar, 0.05 substitutions per nucleotide position. 
We detected isolates $\mathrm{CB} 40, \mathrm{CB} 41$ and $\mathrm{CB} 42^{\mathrm{T}}$ at high frequency [antilog 1010.4 cells $\mathrm{g}^{-1}$ (wet wt)] by using a strictly anaerobic culture-based method (Hayashi et al., 2002a). The 16S rRNA gene sequence of the isolates investigated herein has been detected previously from a 16S rRNA gene sequence library (Hayashi et al., 2002a). These isolates may thus represent an important Bacteroides species occurring in human faeces.

On the basis of the results presented, strains CB40, CB41 and $\mathrm{CB} 42^{\mathrm{T}}$ are considered to represent a novel species of the genus Bacteroides, for which the name Bacteroides coprophilus sp. nov. is proposed. Differential characteristics of B. coprophilus and some related Bacteroides species are given in Table 1.

\section{Description of Bacteroides coprophilus sp. nov.}

Bacteroides coprophilus (cop.ro' phi.lus. Gr. n. copros dung, faeces; Gr. masc. adj. philos friendly to; N.L. masc. adj. coprophilus loving faeces).

Cells are anaerobic, non-spore-forming, Gram-negative short rods or rods. Colonies on EG agar plates after $48 \mathrm{~h}$ incubation at $37^{\circ} \mathrm{C}$ under $100 \% \mathrm{CO}_{2}$ are circular, dark grey, translucent and convex. Grows in the presence of bile. Indole-negative. Aesculin is not hydrolysed. Nitrate is not reduced. No activity is detected for urease or gelatin. Acid is produced from D-glucose, lactose, maltose, D-mannose, Draffinose and sucrose. Positive reactions are obtained using the API Rapid ID 32A system for $N$-acetyl- $\beta$-glucosaminidase, alkaline phosphatase, $\alpha$-fucosidase, $\alpha$-galactosidase, $\beta$ galactosidase, $\alpha$-glucosidase, $\beta$-glucosidase and alanine, arginine, histidine, leucine and leucyl glycine arylamidases. Negative reactions are obtained for $\alpha$-arabinosidase, arginine dihydrolase, $\beta$-galactosidase 6-phosphate, $\beta$-glucuronidase, glutamic acid decarboxylase, nitrate reductase, indole, proline arylamidase and pyroglutamic acid arylamidase. The major end products are succinic and acetic acids; small amounts of isovaleric acid, propionic acid and pyruvic acid are also produced. Major fatty acids are anteiso- $\mathrm{C}_{15: 0}(12-16 \%), \mathrm{C}_{16: 0}(9-12 \%)$, iso- $\mathrm{C}_{17: 0} 3-\mathrm{OH}$ $(17-19 \%)$ and $\mathrm{C}_{18: 1} \omega 9 c(16-18 \%)$. The DNA G+C content of the type strain is $44.7 \mathrm{~mol} \%$.

The type strain, CB42 ${ }^{\mathrm{T}}\left(=\mathrm{JCM} 13818^{\mathrm{T}}=\mathrm{DSM} 18228^{\mathrm{T}}\right)$, was isolated from human faeces. Strains CB40 ( = JCM 13816) and CB41 ( = JCM 13817) are included in this species.

Table 1. Differential characteristics of strain $\mathrm{CB} 42^{\top}$ and type strains of related Bacteroides species

Strains: 1, strain $\mathrm{CB}_{2} 2^{\mathrm{T}}$ (identical results were obtained for strains CB40 and CB41 unless indicated); 2, B. barnesiae JCM 13652 ${ }^{\mathrm{T}}$; 3, B. salanitronis JCM $13657^{\mathrm{T}}$. Data for reference strains were taken from Lan et al. (2006). +, Positive; -, negative; W, weak.

\begin{tabular}{|c|c|c|c|}
\hline Characteristic & 1 & 2 & 3 \\
\hline L-Arabinose & - & - & + \\
\hline L-Rhamnose & - & - & $\mathrm{W}$ \\
\hline Salicin & - & + & $\mathrm{W}$ \\
\hline D-Xylose & - & + & + \\
\hline$N$-Acetyl- $\beta$-glucosaminidase & + & + & - \\
\hline$\alpha$-Arabinosidase & - & + & + \\
\hline Arginine arylamidase & + & - & - \\
\hline$\alpha$-Fucosidase & + & + & - \\
\hline Glutamyl glutamic acid arylamidase & $\mathrm{W}$ & + & + \\
\hline Glycine arylamidase & $\mathrm{W}$ & - & - \\
\hline Tyrosine arylamidase & $\mathrm{W}$ & - & - \\
\hline Serine arylamidase & $\mathrm{W}$ & - & - \\
\hline \multirow[t]{2}{*}{ Major cellular fatty acids } & anteiso- $\mathrm{C}_{15: 0}, \mathrm{C}_{16: 0}$, iso- $\mathrm{C}_{17: 0}$ & anteiso- $\mathrm{C}_{15: 0}$, iso- $\mathrm{C}_{15: 0}$ & anteiso- $\mathrm{C}_{15: 0}$, iso- $\mathrm{C}_{15: 0}$, iso- $\mathrm{C}_{17: 0}$ \\
\hline & $3-\mathrm{OH}, \mathrm{C}_{18: 1} \omega 9 c$ & $\mathrm{C}_{16: 0}, \mathrm{C}_{16: 0} 3-\mathrm{OH}$ & $3-\mathrm{OH}, \mathrm{C}_{16: 0} 3-\mathrm{OH}$ \\
\hline DNA G $+\mathrm{C}$ content $(\mathrm{mol} \%)$ & $44.2-45.2^{\star}$ & 46.8 & 46.9 \\
\hline
\end{tabular}

${ }^{*}$ Range for strains CB40, CB41 and CB42 ${ }^{\mathrm{T}}$. 


\section{Acknowledgements}

We are grateful to Professor Dr Hans Trüper, University of Bonn, Germany, for his suggestions regarding nomenclature.

\section{References}

Bakir, M. A., Kitahara, M., Sakamoto, M., Matsumoto, M. \& Benno, Y. (2006a). Bacteroides intestinalis sp. nov., isolated from human faeces. Int J Syst Evol Microbiol 56, 151-154.

Bakir, M. A., Kitahara, M., Sakamoto, M., Matsumoto, M. \& Benno, Y. (2006b). Bacteroides finegoldii sp. nov., isolated from human faeces. Int J Syst Evol Microbiol 56, 931-935.

Bakir, M. A., Sakamoto, M., Matsumoto, M., Kitahara, M. \& Benno, Y. (2006c). Bacteroides dorei sp. nov., isolated from human faeces. Int J Syst Evol Microbiol 56, 1639-1643.

Benno, Y., Endo, K., Mizutani, T., Namba, Y., Komori, T. \& Mitsuoka, T. (1989). Comparison of fecal microflora of elderly persons in rural and urban areas of Japan. Appl Environ Microbiol 55, 1100-1105.

Eckburg, P. B., Bik, E. M., Bernstein, C. N., Purdom, E., Dethlefsen, L., Sargent, M., Gill, S. R., Nelson, K. E. \& Relman, D. A. (2005). Diversity of the human intestinal microbial flora. Science 308, 1635-1638.

Felsenstein, J. (1985). Confidence limits of phylogenies: an approach using the bootstrap. Evolution 39, 783-791.

Finegold, S. M., Sutter, V. L. \& Mathisen, G. E. (1983). Normal indigenous flora. In Human Intestinal Microflora in Health and Disease, pp. 3-31. Edited by D. J. Hentges. New York: Academic Press.

Hayashi, H., Sakamoto, M. \& Benno, Y. (2002a). Phylogenetic analysis of the human gut microbiota using $16 \mathrm{~S}$ rDNA clone libraries and strictly anaerobic culture-based methods. Microbiol Immunol 46, 535-548.

Hayashi, H., Sakamoto, M. \& Benno, Y. (2002b). Fecal microbial diversity in a strict vegetarian as determined by molecular analysis and cultivation. Microbiol Immunol 46, 819-831.

Holdeman, L. V., Cato, E. P. \& Moore, W. E. C. (1977). Anaerobe Laboratory Manual, 4th edn. Blacksburg, VA: Virginia Polytechnic Institute and State University.

Kimura, M. (1980). A simple method for estimating the evolutionary rates of base substitutions through comparative studies of nucleotide sequences. J Mol Evol 16, 111-120.

Kitahara, M., Takamine, F., Imamura, T. \& Benno, Y. (2001). Clostridium hiranonis sp. nov., a human intestinal bacterium with bile acid $7 \alpha$-dehydroxylating activity. Int J Syst Evol Microbiol 51, 39-44.

Kitahara, M., Sakamoto, M., Ike, M., Sakata, S. \& Benno, Y. (2005). Bacteroides plebeius sp. nov. and Bacteroides coprocola sp. nov., isolated from human faeces. Int J Syst Evol Microbiol 55, 2143-2147.

Lan, P. T. N., Sakamoto, M., Sakata, S. \& Benno, Y. (2006). Bacteroides barnesiae sp. nov., Bacteroides salanitronis sp. nov. and Bacteroides gallinarum sp. nov., isolated from chicken caecum. Int J Syst Evol Microbiol 56, 2853-2859.

Matsuki, T., Watanabe, K., Fujimoto, J., Takada, T. \& Tanaka, R. (2004). Use of $16 \mathrm{~S}$ rRNA gene-targeted group-specific primers for real-time PCR analysis of predominant bacteria in human feces. Appl Environ Microbiol 70, 7220-7228.

Mayberry, W. R., Lambe, D. W., Jr \& Ferguson, K. P. (1982), Identification of Bacteroides species by cellular fatty acid profiles. Int J Syst Bacteriol 32, 21-27.

Mitsuoka, T., Morishita, Y., Terada, A. \& Yamamoto, S. (1969). A simple method ("plate-in-bottle method") for the cultivation of fastidious anaerobes. Jpn J Microbiol 13, 383-385.

Miyagawa, E., Azuma, R. \& Suto, T. (1979). Cellular fatty acid composition in gram-negative obligately anaerobic rods. J Gen Appl Microbiol 25, 41-51.

Saitou, N. \& Nei, M. (1987). The neighbor-joining method: a new method for reconstructing phylogenetic trees. Mol Biol Evol 4, 406-425.

Sakamoto, M., Suzuki, M., Umeda, M., Ishikawa, I. \& Benno, Y. (2002). Reclassification of Bacteroides forsythus (Tanner et al. 1986) as Tannerella forsythensis corrig., gen. nov., comb. nov. Int J Syst Evol Microbiol 52, 841-849.

Sakamoto, M., Suzuki, M., Huang, Y., Umeda, M., Ishikawa, I. \& Benno, Y. (2004). Prevotella shahii sp. nov. and Prevotella salivae sp. nov., isolated from the human oral cavity. Int J Syst Evol Microbiol 54, 877-883.

Sakamoto, M., Huang, Y., Umeda, M., Ishikawa, I. \& Benno, Y. (2005). Prevotella multiformis sp. nov., isolated from human subgingival plaque. Int J Syst Evol Microbiol 55, 815-819.

Sakka, K., Furuse, S. \& Shimada, K. (1989). Cloning and expression in Escherichia coli of thermophilic Clostridium sp. F1 genes related to cellulose hydrolysis. Agric Biol Chem 53, 905-910.

Shah, H. N. \& Collins, M. D. (1980). Fatty acid and isoprenoid quinone composition in the classification of Bacteroides melaninogenicus and related taxa. J Appl Bacteriol 48, 75-87.

Shah, H. N. \& Collins, M. D. (1983). Genus Bacteroides. A chemotaxonomical perspective. J Appl Bacteriol 55, 403-416.

Stackebrandt, E. \& Goebel, B. M. (1994). Taxonomic note: a place for DNA-DNA reassociation and $16 \mathrm{~S}$ rRNA sequence analysis in the present species definition in bacteriology. Int J Syst Bacteriol 44, 846-849.

Suau, A., Bonnet, R., Sutren, M., Godon, J.-J., Gibson, G. R., Collins, M. D. \& Doré, J. (1999). Direct analysis of genes encoding $16 \mathrm{~S}$ rRNA from complex communities reveals many novel molecular species within the human gut. Appl Environ Microbiol 65, 4799-4807.

Tamaoka, J. \& Komagata, K. (1984). Determination of DNA base composition by reversed phase high-performance liquid chromatography. FEMS Microbiol Lett 25, 125-128.

Thompson, J. D., Higgins, D. G. \& Gibson, T. J. (1994). CLUSTAL W: improving the sensitivity of progressive multiple sequence alignment through sequence weighting, position-specific gap penalties and weight matrix choice. Nucleic Acids Res 22, 4673-4680.

Wilson, K. H. \& Blitchington, R. B. (1996). Human colonic biota studied by ribosomal DNA sequence analysis. Appl Environ Microbiol 62, 2273-2278.

Zoetendal, E. G., Akkermans, A. D. \& de Vos, W. M. (1998). Temperature gradient gel electrophoresis analysis of $16 \mathrm{~S}$ rRNA from human fecal samples reveals stable and host-specific communities of active bacteria. Appl Environ Microbiol 64, 3854-3859. 